Acta vet. scand. $1973,14,168-175$.

From the Department of Food Hygiene,

Veterinary College of Norway, Oslo.

\title{
PROTEOLYTIC AND LIPOLYTIC ENZYMES FROM LARVAE OF OEDEMAGENA TARANDI (L.)
}

By

Kjell Aurstad and Alv Helge Skeie

\begin{abstract}
AURSTAD, KJELL and ALV HELGE SKEIE: Proteolytic and lipolytic enzymes from larvae of Oedemagena tarandi (L.). Acta vet. scand. 1973, 14, 168-175. - Some biological properties of proteolytic and lipolytic enzymes of the larval stages of Oedemagena tarandi (L.) were examined. While the proteinase titres seemed to vary only slightly from one larval stage to another, the lipase titres of the first larval stage seemed to be much greater than those of the second and third larval stages. The zymogram technique used showed only one proteinase, which was inhibited by all the biological inhibitors tested. Bacteriological examinations of the external surfaces and internal organs of the different larval stages showed only a very sparse flora.

Oedemagena tarandi (L.); proteolytic enzyme; lipolytic enzyme; biological inhibitors.
\end{abstract}

Intensive studies on the biology and the economic importance of Oedemagena tarandi (L.) have been made by Hadwen (1926), Breev \& Karazeeva (1952, 1953) and Breev \& Savelev (1954).

Although Thorsell \& Nordquist (1962) described some hydrolyzing enzymes in larvae of $O$. tarandi, little is known about the biological properties of the enzymes of the larval stages of this insect. Knowledge of the enzymes secreted by the immature, and adult, stages of insects may be of value in the search for new insecticides (Thorsell \& Nordquist). Furthermore, such enzymological studies may be of significance for meat spoilage prevention, and in taxonomic and phylogenetic work (Dahle et al. 1971, Hilali et al. 1972).

The aim of the present work was to elucidate some of the biological properties of the proteinases and lipases of the im- 
mature stages of $O$.tarandi. Furthermore, it was considered worthwhile to determine the normal bacterial flora of the larvae of this insect.

\section{MATERIALS AND METHODS}

\section{Collection of larvae}

First, second and thind stage larvae of O. tarandi were collected from subcutaneous tissue of freshly slaughtered reindeer in the northern part of Norway. The material was delivered to the laboratory no later than $35 \mathrm{hrs}$. after slaughtering, and then stored at $-20^{\circ} \mathrm{C}$ unitil used.

The identification of the larvae was performed according to Zumpt (1965).

\section{Enzymological examinations}

The material to be examined was macerated and centrifuged. The supernatants were removed by suction and stored at $-20^{\circ} \mathrm{C}$ until used. The supernatants were examined for proteinases according to the casein precipitating method of Sandvik (1962), and for lipases according to the agar gel method, incorporating tributyrin as substrate (Ellinghausen \& Sandvik 1965).

Titrations of the proteinase activities were carried out by transferring aliquots of $25 \mu 1$ from serial 2 -fold dilutions of the solutions to wells of $7 \mathrm{~mm}$ diameter in sodium caseinate containing agar, followed by incubation at $37^{\circ} \mathrm{C}$ for $16 \mathrm{hrs}$. The estimation of diffusion units was based on the diameters of the precipitation zones which occurred (Dahle 1969).

The effects of naturally occurring proteinase inhibitors of various animal sera on the proteinases of the larval stages of $O$. tarandi were tested by the crosswise casein precipitation inhibition test (CPI-test) of Fossum (1970).

Zymograms of the proteinases of the larvae were prepared in agar gels by the electrophoretical procedure described by Dahle (1970).

\section{Bacteriological examinations}

The external surfaces and internal organs of the larvae were examined according to general bacteriological procedures. Incubations were performed aerobically, anaerobically, and in an atmosphere of $10 \% \mathrm{CO}_{2}$ at $30^{\circ} \mathrm{C}$ and $37^{\circ} \mathrm{C}$, and the organisms 
were identified on the basis of cultural and physiological properties (Breed et al. 1957).

\section{RESULTS}

The extracts of the macerated larvae of different stages were examined for proteinases and lipases by two separate agar diffusion methods. Fig. 1a shows precipitation zones of casein in agar gel caused by proteinases extracted from the third stage larvae, while Fig. 1b shows transparent zones of hydrolyzed tributyrin caused by lipases from the same sample. The figure
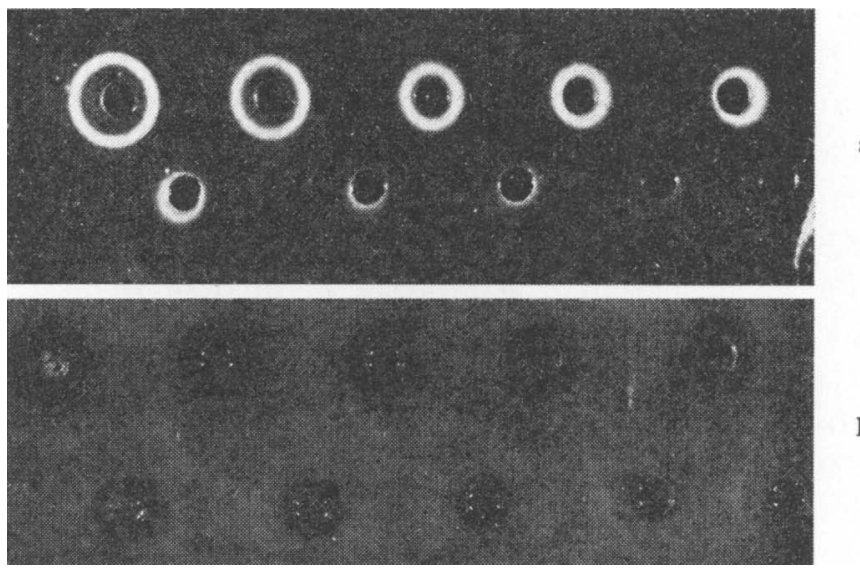

Figure 1. Titration of casein precipitating enzymes in sodium caseinate-agar gel (a), and lipolytic enzymes in tributyrin-agar gel (b). The titres of casein precipitating enzymes are determined using standard curves obtained when the diameters of the zones, caused by the enzymes in serial 2-fold dilutions, are plotted against the logarithm of the degree of dilution.

also shows the decreasing diameters of the zones throughout the dilution series, and this was used as the basis for the estimation of the concentrations of the enzymes in the various extracts.

Using the procedure for the estimation of diffusion units described by Sandvik (1962), and modified by Dahle (1969), the proteinase concentration in the particular enzyme solution prepared was of the order of ca. 16,000 diffusion units per $\mathrm{ml}$. The 
proteinase concentrations seemed to vary only slightly from one larval stage to another.

The tributyrinase titres for the different larval stages are listed in Table 1 . The first larval stage seemed to possess much greater tributyrinase activity than the third stage larvae.

Ta b l e 1. Tributyrinase titres of different larval stages of Oedemagena tarandi $(L)$.

\begin{tabular}{ll}
\hline Samples & Titres \\
\hline First stage larva & $1: 4096$ \\
Second stage larva & $1: 2048$ \\
Third stage larva & $1: 512$ \\
\hline
\end{tabular}

In order to investigate whether more than one proteinase was present in the extracts, zymograms were prepared in agar gels. However, these revealed only one proteinase, with cathodic migration, at $\mathrm{pH} 6.2$.

In contrast to the larvae of Calliphora erythrocephala, no external lipolytic or proteolytic enzymes could be demonstrated in any of the larval stages of O. tarandi (Dahle et al. 1971).

The crosswise CPI-test was used to examine for resistance against naturally occurring proteinase inhibitors, and inhibitors from various blood sera were tested. The effects of some of these inhibitors are shown in Fig. 2, where it can be seen that the proteinases are inhibited by all the inhibitors studied.

The external surface and internal organs of the larvae were examined bacteriologically. By the methods used, only a very sparse flora consisting of micrococci and enterobacteria was isolated from the different larval stages of $O$. tarandi.

\section{DISCUSSION}

Proteinases and lipases from insects have been thoroughly described by several authors (Thomsen 1952, 1954, Thomsen \& Mфller 1959, 1963, Dahle et al. 1971 and Hilali et al. 1972). Among the food spoiling enzymes, proteinases and lipases are of particular interest (Dahle 1971b), and they can be conveniently demonstrated by the agar diffusion methods used in the present study. 


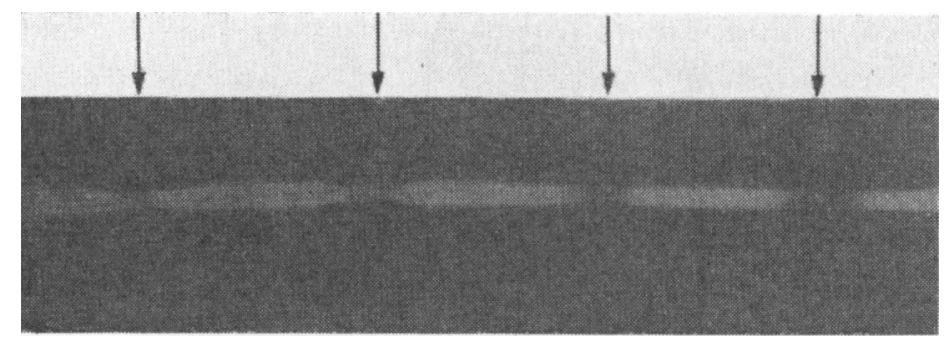

F ig u re 2. Demonstration of proteinase inhibitors by the crosswise CPI-test. Narrow filter paper strips moistened with solutions of inhibitors were placed on sodium caseinate-agar plates, and incubated for $3 \mathrm{hrs}$. at $37^{\circ} \mathrm{C}$. After removal of these strips, a similar strip, moistened with the proteinase solution, was applied to the surface of the agar gel at right-angles to the direction of application of the inhibitors, and the plate incubated for a further 16 hours at $37^{\circ} \mathrm{C}$. Proteolytic activity is indicated by the greyish-white zones in the transparent agar, while inhibition is indicated by interruptions in the precipitation zones. The inhibitors are, from left to right as marked by arrows: reindeer-serum, cow-serum, horse-serum and sheep-serum.

Although the determinations of the enzymes are semiquantitative, and do not represent the exact amounts of enzymes present in the materials, the casein precipitating activity, and the lipolytic activity of the solutions indicated that the larvae of O. tarandi possessed very high biocatalytic activities (Fig. 1 and Table 1). This is also in accordance with the findings of Dahle et al. and Hilali et al. for the larvae of Calliphora erythrocephala, and larvae and imagos of Dermestes landarius. While there was no distinct difference in the proteolytic activities of the three larval stages of $O$. tarandi, the first larval stage seemed to have a much higher lipolytic activity than the other ones (Table 1). The problem of induced enzymes in animals and insects has not been thoroughly analysed as in certain types of yeasts and bacteria (Rose 1968, Dahle 1971a). Some reports from entomologists, however, indicate that the problem is of importance for insects. Thus Thomsen \& M Mller (1963) found that the proteolytic activity of the adult female of Calliphora erythrocephala is highly influenced by the diet during the first 5 days after emergence.

The high lipolytic activity of the first larval stage of O. tarandi may be connected with the migration of this larva in the 
connective tissue and the muscles towards the rump and spine of the host.

The existence of more than one proteinase fraction in proteinase producing organisms is a basic problem in nature which has been discussed for some bacterial proteinase systems by Dahle (1971b). Hilali et al. demonstrated three proteolytic fractions from macerated larvae and imagos of Dermestes lardarius using the zymogram technique. However, not more than one proteinase fraction could be demonstrated from macerated larvae of $O$.tarandi using the same technique. At present, the zymogram technique for lipases has not been finally standardized, but the number of lipase fractions and their mutual relationships are also of interest, together with the proteinases, for possible application in taxonomical and phylogenetic studies (Hilali et al.).

In contrast to inhibitors against proteinases, naturally occurring inhibitors against lipolytic enzymes have not been demonstrated in animal blood sera. It is difficult to give a biological interpretation of this phenomenon although the problems could be of significance for developing control systems for insects.

Bacteriological examinations were carried out in order to elucidate wether transmission of putrifying microorganisms through the larval stages in the life cycle of the warble-fly occurred. The results indicate, however, that only a sparse flora is to be found in the larvae. The microorganisms found may be due to contamination arising during the transport to the laboratory of the material for the investigations.

\section{REFERENCES}

Breed, R. S., E. G. D. Murray \& N. R. Smith: Bergey's manual of determinative bacteriology. 7th Ed., Williams \& Wilkins Co., Baltimore, Maryland 1957.

Breev, K. A. \& Z. F. Karazeeva: Materials relating to the biology of the warble-fly Oedemagena tarandi (L.). 1. Observations on the periods of embryonic development and mode of life of the first instar larvae. Parazit. Sborn. 1952, 14, 95-102.

Breev, K. A. \& Z. F. Karazeva: Materials relating to the biology of the warble-fly of reindeer Oedemagena tarandi (L.). 2. Observations on the larvae of the second and third instar. Parazit. Sborn. 1953, 15, 410-424.

Breev, K. A. \& D. V. Savelev: The control of the reindeer warble-fly. Veterinariya $1954,21,35-37$. 
Dahle, $H . K .:$ Quantitative assay of a single proteolytic enzyme in a crude mixture of bacterial proteinases. Acta path. microbiol. scand. 1969, Section B, 77, 134-142.

Dahle, $H$. K.: Zymograms in agar gel of some animal and bacterial proteinases. Acta path. microbiol. scand. 1970, 78, 575-578.

Dahle, $H$. $K$.: Regulation of the proteinase production in two strains of Aeromonas. Acta path. microbiol. scand. 1971a, Section B, 79, 739-746.

Dahle, H. K.: Enzymoserological, Biochemical and Biophysical Analyses of Some Bacterial Proteinase Systems. Universitetsforlaget, Oslo $1971 \mathrm{~b}$.

Dahle, H. K., M. Hilali \& J. Nordal: Proteolytic enzymes of Calliphora erythrocephala (Meigen) larvae and their significance in meat spoilage. Acta agric. scand. 1971, 21, 183-188.

Ellinghausen, H. C. \& O. Sandvik: Tributyrinase activity of leptospires. Fixed and soluble tributyrinase demonstrated by means of an agar diffusion test. Acta path. microbiol. scand. 1965, 65, $259-270$.

Fossum, K.: Proteolytic enzymes and biological inhibitors. II. Naturally occurring inhibitors in sera from different species and their effect upon proteolytic enzymes of various origin. Acta path. microbiol. scand. 1970, Section B, 78, 605-618.

Hadwen, S.: Notes on the life-history of Oedemagena tarandi (L.), and Cephenomyia trompe (Modeer). J. Parasit. 1926, 13, 56-65.

Hilali, M., H. K. Dahle \& K. Aurstad: Life history and food-spoiling enzymes of Dermestes lardarius (L.). Norsk entomol. T. 1972, $19,25-32$.

Rose, A. H.: Chemical Microbiology. Scand. ed. Butterworths and Co. Ltd., 2nd Ed., London 1968.

Sandvik, O.: Studies on casein precipitating enzymes of aerobic and facultatively anaerobic bacteria. Thesis. Veterinary College of Norway, Oslo 1962.

Thomsen, Ellen: Functional significance of the neurosecretory brain cells and the corpus cardiacum in the female blow-fly, Calliphora erythrocephala Meig. J. exp. Biol. 1952, 29, 137-172.

Thomsen, Ellen: Studies on the transport of neurosecretory material in Calliphora erythrocephala by means of ligaturing experiments. J. exp. Biol. 1954, 31, 322-330.

Thomsen, Ellen \& J. Møller: I. Neurosecretion and intestinal proteinase activity in an insect, Calliphora erythrocephala Meig. Nature (Lond.) 1959, 183, 1401-1402.

Thomsen, Ellen \& J. Mфller: Influence of neurosecretory cells and corpus allatum on intestinal protease activity in the adult Calliphora erythrocephala Meig. J. exp. Biol. 1963, 40, 301-321.

Thorsell, W. \& M. Nordquist. Några hydrolyserande enzym hos larver av Oedemagena tarandi (L.). (Some hydrolyzing enzymes in larvae of Oedemagena tarandi (L.). Beretn. 9. Nord. vet.-møte, København 1962, 216-220.

Zumpt, F.: Myiasis in man and animals in the old world. Scand. ed. Butterworths and Co. Ltd., 1st Ed., London 1965. 


\section{SAMMENDRAG}

Proteolytiske og lipolytiske enzymer fra larver af Oedemagena tarandi (L.).

Biologiske egenskaper hos proteolytiske og lipolytiske enzymer fra larvestadier hos Oedemagena tarandi (L.) ble unders $\varnothing$ kt. Mens proteinasetitret fra det ene larvestadiet til det andre varierte bare ubetydelig, ble lipase-titret hos det første larvestadiet funnet å være mye større enn hos det andre og tredje larvestadiet. Med hjelp av zymogram-teknikk kunne det bare påvises en proteinase, og denne ble inhibert av alle de biologiske inhibitorene som ble prøvd. Bakteriologiske unders $\varnothing$ kelser av overflate og indre organer av de forskjellige larvestadier viste bare en meget sparsom flora.

(Received October 5, 1972).

Reprints may be requested from: Kjell Aurstad, Department of Food Hygiene, Veterinary College of Norway, Postbox 8146, Oslo Dep., Oslo 1, Norway. 